\title{
АДАПТАЦІЯ ВІЛЬНО РОЗПОВСЮДЖУВАНОГО ПЗ 3 ВІДКРИТИМ КОДОМ MOODLE ДЛЯ ПІДТРИМКИ НАВЧАЛЬНОГО ПРОЦЕСУ У МЕДИЧНОМУ ВНЗ
}

\author{
А. В. Семенець
}

ДВНЗ «Тернопільський державний медичний університет імені І. Я. Горбачевського МОЗ України»

\begin{abstract}
Застосування вільно розповсюджуваного ПЗ з відкритим кодом є важливим елементом сучасного підходу до реалізації навчального процесу в медичній освіті. Показаний досвід впровадження, адаптації та підтримки системи дистанційної освіти Moodle в Тернопільському державному медичному університеті імені І. Я. Горбачевського. Наведено приклади застосування системи контролю версій для підтримки процесу адаптації та супроводження вільно розповсюджуваного ПЗ з відкритим кодом.
\end{abstract}

Ключові слова: медична освіта, програмне забезпечення з відкритим кодом, розробка програмного забезпечення, система дистанційної освіти, система контролю версій.

\section{АДАПТАЦИЯ СВОБОДНО РАСПРОСТРАНЯЕМОГО ПО С ОТКРЫТЫМ КОДОМ MOODLЕ ДЛЯ ПОДДЕРЖКИ УЧЕБНОГО ПРОЦЕССА В МЕДИЦИНСКИХ ВУЗАХ}

\author{
ГВУЗ «Тернопольский государственный медицинский университет \\ имени И. Я. Горбачевского мОз Украины»
}

\begin{abstract}
Применение свободно распространяемого ПО с открытым кодом является важным элементом современного подхода к реализации учебного процесса в медицинском образовании. Показан опыт внедрения, адаптации и поддержки системы дистанционного образования Moodle в Тернопольском государственном медицинском университете имени И. Я. Горбачевского. Приведены примеры применения системы контроля версий для поддержки процесса адаптации и сопровождения свободно распространяемого пО с открытым кодом.
\end{abstract}

Ключевые слова: медицинское образование, программное обеспечение с открытым кодом, разработка программного обеспечения, система дистанционного образования, система контроля версий.

\section{OPEN-SOURCE MOODLE SOFTWARE ADAPTATION SUPPORTING MEDICAL UNIVERSITY ACADEMIC PROCESS}

\section{A. V. Semenets}

SHEI «Ternopii State Medical University by I. Ya. Horbachevsky of MPH of Ukraine»

\begin{abstract}
An open-source software application is an important part of the modern approach to the medical education. The experience of the Moodle learning management system in Ternopil State Medical University by I. Ya. Horbachevsky implementation, adaptation and support was presented. Examples of application of the version control system to the open-source software adaptation and support also was shown.
\end{abstract}

\begin{abstract}
Key words: medical education, open-source software, learning management system, software development, distance education system, version control system.
\end{abstract}

Вступ. Інформатизація системи охорони здоров'я належить до числа ключових загальнодержавних завдань. Застосування інформаційних технологій в системі охорони здоров'я та медичної освіти набуває щораз більшого значення. Медична інформатика у поєднанні з організаційними змінами в закладах охорони здоров'я сприяє наданню якіснішої медичної допомоги, одночасно зменшуючи фінансові видатки. При цьому галузь медичної освіти повинна забезпечити підготовку фахівців, здатних ефективно використовувати можливості сучасних медичних інформаційних систем, брати участь у їх розробці та супроводженні [I].

(C) А. В. Семенець 


\section{I. Розробка та впровадження сучасних про-} грамних додатків в медичній освіті

Серед концептуальних напрямків впровадження сучасних інформаційних технологій у галузі медичної освіти автор на перше місце стравить впровадження інформаційних систем (1C) керування навчанням (СКН чи LMS - Learning management system), які часто поєднані з системами дистанційної освіти (СДО), та систем керування навчальними матеріалами (СКНМ або LCMS - learning content management system).

За останні роки в галузі медичної освіти України суттєво активізувалася діяльність 3 впровадження вказаних типів 1С підтримки навчального процесу $[2,3,4]$. Кількість інсталяцій окремих 1 С вже налічує кілька сотень [5]. Тривають процеси розробки і впровадження різноманітного ПЗ СКН/СДО/СКНМ вітчизняного виробництва. Однак цей напрямок $€$ одночасно і найбільш проблемним. Нерідко проекти 3 впровадження ПЗ СКН/СДО/СКНМ здійснюються 3 численними промахами і помилками. В результаті проекти не досягають поставлених цілей, даремно витрачаються фінансові ресурси, втрачається час та зусилля як технічних працівників так і професорсько-викладацького складу навчальних закладів. Останній факт завдає ще i значної шкоди власне якості підготовки фахівців оскільки викладачі ВНЗу зайняті не навчальною чи науковою роботою, а обслуговуванням невідповідного/недосконалого/застарілого ПЗ СКН/СДО/СКНМ.

Довільний проект автоматизації освітніх процесів у медичному навчальному закладі можна реалізувати в рамках наступних трьох альтернативних підходів:

1. Впровадження існуючого комерційного ПЗ СКН/ СДО/СКНМ.

2. Адаптація вільно розповсюджуваного ПЗ СКН/ СДО/СКНМ з відкритим кодом.

3. Розробка власного, спеціально спроектованого ПЗСКН/СДО/СКНМ.

3 точки зору автора, розробка ще однісї СКН/ СДО/СКНМ є невиправданою. В абсолютній більшості випадків раціональним і виправданим кроком буде застосування вже існуючої СКН/СДО/СКНМ. Для прикладу, Вікіпедія пропонує перелік з більш ніж 40 провідних СКН/СДО/СКНМ світового рівня, 14 з яких - вільно розповсюджуване ПЗ з відкритим кодом [6]. Сховище ПЗ з відкритим кодом, сайт Sourceforge (http://sourceforge.net), видає більше 30 проектів з статусом "стабільний додаток" за запитом "LMS" [7].
2. Застосування вільно розповсюджуваного ПЗ 3 відкритим кодом в навчальному процесі ТДМУ Безперечними лідерами серед ПЗ СКН/СДО/ CКНМ $з$ відкритим кодом є СДО Moodle (http:// moodle.org/) та aTutor (http://atutor.ca/), що мають величезний набір функцій та широко застосовуються в навчальних закладах багатьох країн світу. Зокрема, на сайті спільноти Moodle офіційно зареєстровано більше 100 українських навчальних закладів, що використовують СДО Moodle [5]. Реально їх може бути ще більше, оскільки реєстрація є добровільною та необов'язковою.

Позитивними рисами ПЗ СКН/СДО/СКНМ з відкритим кодом від провідних світових розробників $є$ :

- безкоштовний характер поширення ПЗ;

• широкі функціональні можливості, що охоплюють різні аспекти організації навчального процесу;

- гнучкість налаштування системи та добра масштабованість;

- крос-платформеність - більшість ПЗ СКН/СДО/ СКНМ з відкритим кодом є веб-орієнтованими додатками і можуть працювати на будь-якій платформі, включно з сучасними мобільними пристроями;

- доступність вихідних кодів та програмних інтерфейсів для створення власних доповнень.

Найхарактернішими негативними рисами ПЗ СКН/ СДО/СКНМ з відкритим кодом від іноземних розробників $\epsilon$ :

- суттєві відмінності у підходах до організації навчального процесу у порівнянні з усталеними формами, що склалися в Україні;

- відсутність україномовної локалізації;

- слабка (часто взагалі відсутня) безкоштовна технічна підтримка.

Вказані недоліки не є перешкодою до використання ПЗ СКН/СДО/СКНМ $з$ відкритим кодом в системі медичної освіти України. Важливо лише застосувати ряд правильних підходів до використання такого ПЗ. Більше того, впровадження може бути здійснено силами лише технічного персоналу та професорсько-викладацького закладу медичної освіти.

Прикладом цього твердження є застосування СДО Moodle в Тернопільському державному медичному університеті ім. І. Я. Горбачевського. Впровадження цієї СДО в навчальний процес ТДМУ розпочалося у 2006 році (версія Moodle 1.6) і здійснювалося силами персоналу ТДМУ. Впродовж наступних років відбувалося наповнення СДО Moodle навчальними матеріалами. Динаміка змін основних показників СДО Moodle ТДМУ лише протягом 2 останніх років показана в таблиці нижче: 


\begin{tabular}{|c|c|c|c|c|c|c|}
\hline період & курсів & користувачів & викладачів & записів на лрси & ресурсів & тестових завдань \\
\hline $01 / 2012$ & 1452 & 6783 & 752 & 98315 & 13 & 2728034 \\
\hline $01 / 2013$ & 1485 & 6800 & 746 & 99474 & 2933 & 2809977 \\
\hline $11 / 2013$ & 1571 & 7647 & 766 & 104223 & 7851 & 3139582 \\
\hline
\end{tabular}

В процесі експлуатації було здійснено оновлення (за ініціативи автора) СДО Moodle до версії 2.0, що є дуже непростою процедурою [8]. Здійснюється адаптація окремих модулів у відповідності до особливостей навчального процесу ТДМУ (див. нижче). Це дозволяє розширити сферу застосування СДО Moodle і підвищити його роль в навчальному процесі ТДМУ. Триває процес наповнення його навчальними матеріалами 3 веб-сайту сервера інтранет ТДМУ, а це близько 500 Гб даних, більше половини 3 яких - відеоматеріали до занять та лекцій.

Автор повинен відзначити велику кількість фактів нерозуміння (аж до відкритого супротиву), професорсько-викладацьким складом i, на жаль, частиною адміністрації ВУЗів, необхідності як підтримання СДО МооШе в актуальному стані, так і розвитку процесу інтеграції даного СДО в навчальний процес - що $є$ очевидною вимогою забезпечення сучасного європейського рівня підготовки фахівців.

3. Адаптація функціональних можливостей СДО Moodle до особливостей навчального процесу в ТДМУ

\section{1. Модифікації ядра СДО Moodle}

До $20 \mathrm{I} 2$ року СДО Moodle в навчальному процесі ТДМУ використовувалося головно для здійснення тестового контролю при самопідготовці студентів до занять в рамках кредитно-модульної системи організації навчального процесу (КМСОНП). Склад модулів СДО Moodle залишався стандартним, однак програмісти ТДМУ внесли ряд модифікацій в програмний код деяких модулів, зокрема:

- змінено методику оцінювання результатів тестування, згідно з методикою, прийнятою в ТДМУ;

- введено детальну реєстрацію та логування процесу задання параметрів тестування для здійснення контролю виконання викладачами вказівок адміністрації ВУЗу;

- реалізовано численні дрібні зміни в інтерфейсі СДО Moodle з метою забезпечення більш комфортної роботи користувачів.

Слід відмітити черговий негативний факт - документування змін практично не велося. Дуже швидко це призвело до того, що оновлювати програмний код СДО Moodle стало неможливо - зокрема, через зміну кадрового складу програмістів.
В серпні 20I2 року автором було висунуто ініціативу про оновлення СДО Moodle. При цьому автор здійснив повну інвентаризацію всіх змін, що були внесені програмістами ТДМУ в програмний код СДО Moodle версії I.9. Більшу частину 3 них було адаптовано у відповідності до вимог версій 2.x. Для цього було використано можливості системи контролю версій (СКВ) git (http:/gitscm.com/), зокрема:

- інструмент пошуку відмінностей diff - для пошуку та відображення відмінностей між офіційною редакцією коду СДО Moodle та кодом, що знаходився на сервері ТДМУ.

- засіб створення гілок branch - для формування гілок, кожна з яких містить зміни в програмному коді, що реалізують окремі функції ПЗ. Таким чином автором було повторно реалізовано функціональність, специфічну для ТДМУ, у версії 2.0 СДО Moodle (рис. I).

- інструмент commit, який формує підтверджений блок змін в гілці програмного коду і дає можливість явним чином відобразити послідовність створення/ модифікації коду.

- операція злиття гілок merge, яка дозволяє поєднати програмний код з двох різних гілок. Таким чином, автором було здійснено повторну інтеграцію гілок 3 окремими функціональними можливостями в єдину фінальну гілку, код з якої і було завантажено на основний сервер СДО Moodle ТДМУ (рис. I).

- засіб обробки конфліктів resolve, який дозволяє відслідковувати конфлікти в програмному коді при злитті гілок, відображає їх, та надає можливості вибору блоків чи редагування коду - для вирішення цих конфліктів.

За результатами вказаної роботи автором створено окремий репозиторій версії СДО Моodle для ТДМУ, який опубліковано як відгалуження основного проекту на сервері GitHub(https:/github.com/ semteacher/moodle/). Вказаний репозиторій регулярно оновлюсться за допомогою вбудованих засобів СКВ git, у відповідності з виходами стабільних релізів СДО Moodle. Тим самим забезпечується підтримка версії програмного коду СДО Moodle для ТДМУ в актуальному стані. На рис. I показано частину дерева ревізій програмного коду СДО Moodle 3 вказаного репозиторію - лише найбільш актуальні гілки, отримані засобами СКВ git. 


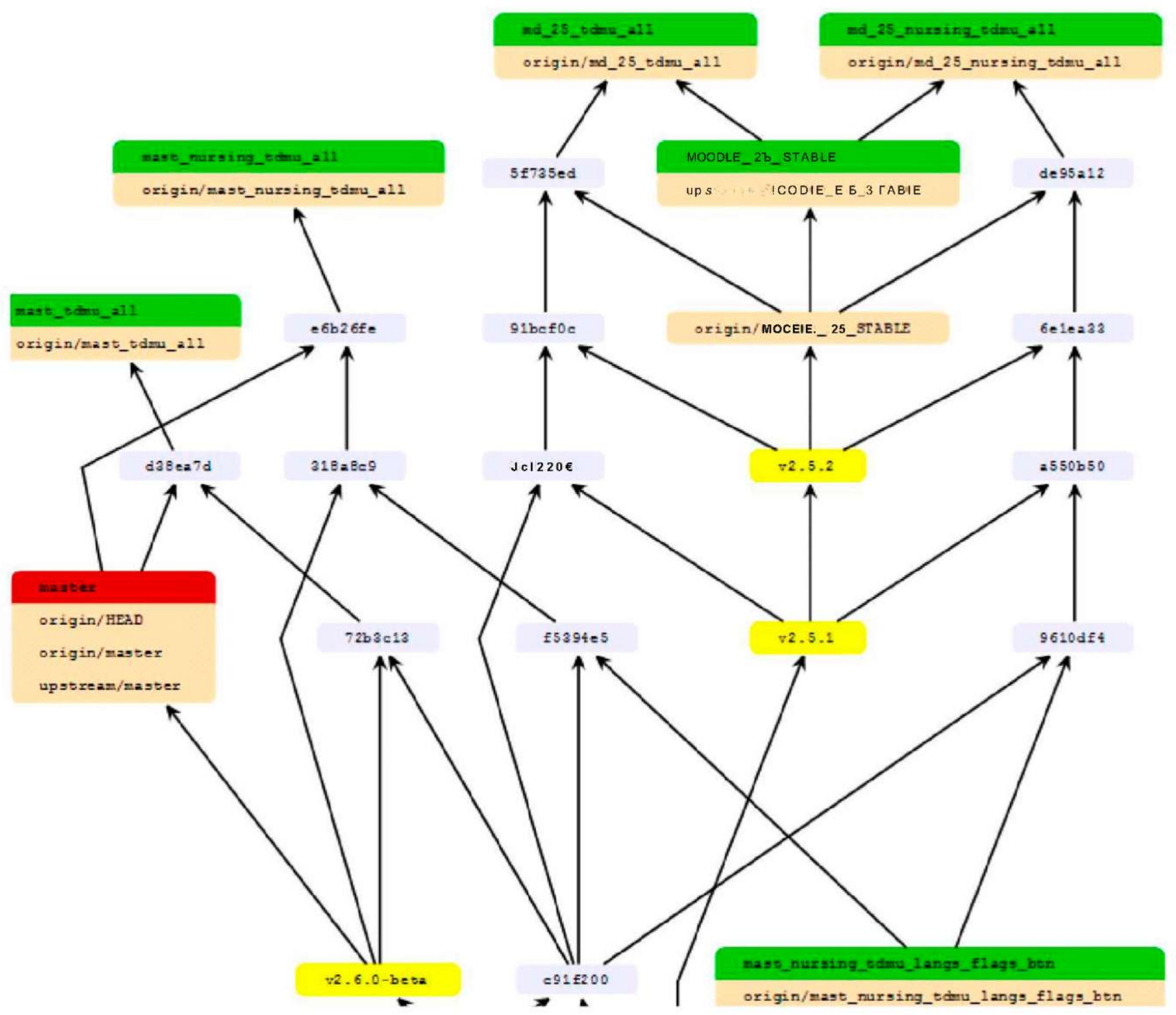

Puc. I. Фрагмент дерева ревізій програмного коду СДО Moodle.

\section{2. Розширення функціональних можливос-} тей СДО Moodle в ТДМУ

\section{2Л. Представлення оцінок виконання}

\section{практичних навичок студентами}

Автор вперше долучився до процесу супроводження і підтримки СДО Moodle на початку 20I2 року, коли було прийнято рішення про публікацію в СДО Moodle результатів окремих нових методик, що застосовуються навчальному процесів ТДМУ. Це, зокрема, оцінювання практичних навиків, що здійснюється викладачами кафедр університету 3 реєстрацією результатів у матрикульних книгах студентів. Та Об'єктивний Структурований Клінічний Іспит (OCKI),який застосовується для комплексної перевірки практичних навиків студентів 33 по 6 курс
Для реалізації вказаного завдання автор додав в СДО Moodle ТДМУ новий функціональний модуль (плагін), що дозволяє створювати, редагувати та відмічати виконання студентами контрольних списків навиків чи знань. Таким чином, за допомогою контрольного списку відображається ступінь виконання матрикулу практичних навичок студентом. По результатах дослідної експлуатації протягом весняного семестру 20I2року модуль ведення контрольних списків був модернізований $з$ метою забезпечити також реєстрацію оцінок, отриманих студентами на ОСКІ (рис. 2).

Вказаний модуль був розроблений на основі модуля виду діяльності Checklist для СДО Moodle [ 10, II] 3 використанням мови програмування РНР. Для керування процесом модифікації програмного коду мо- 

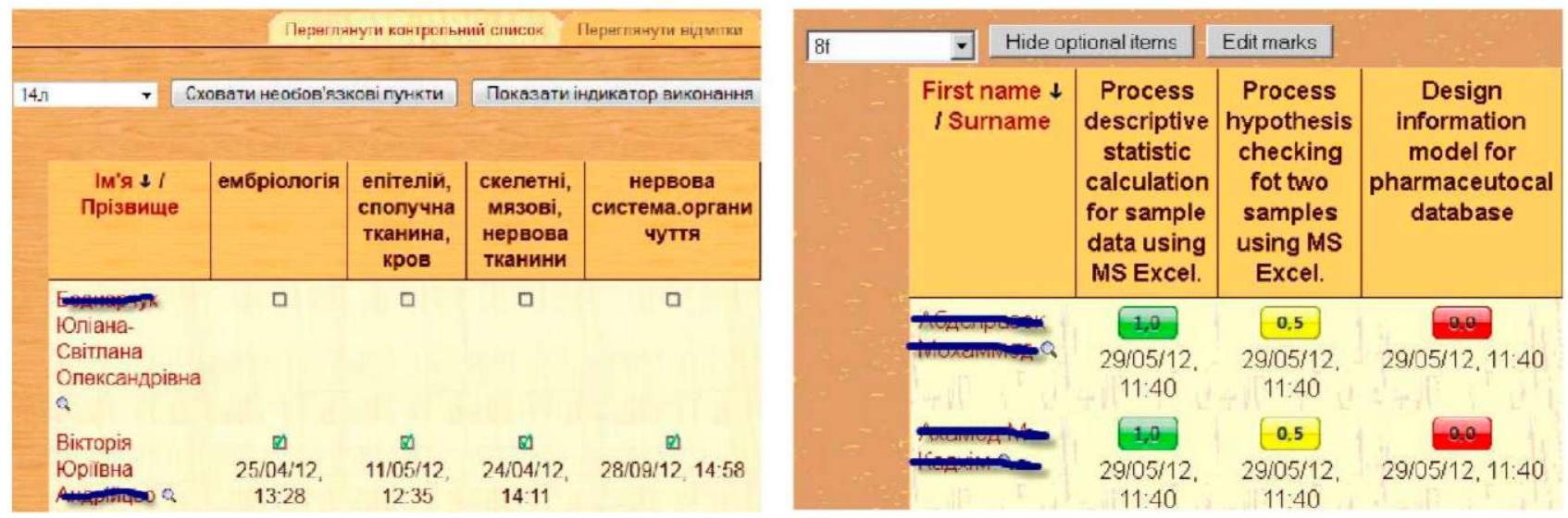

Puc. 2. Відмітки матрикулів студентів та їх оцінки на ОСКІ.

дуля вперше в практиці програмістів ТДМУ застосовано систему контролю версій git (рис. 3). Сам модифікований модуль опубліковано, як відгалужен- ня основного проекту, в репозиторії автора (https:// github.com/semteacher/moodle-checklist/)на сервері GitHub (https ://github.com/).

\section{The moodle-checklist network graph}

All branches in the network using davosmith/moodle-checklist as the reference point. Read our blog post about how it works.

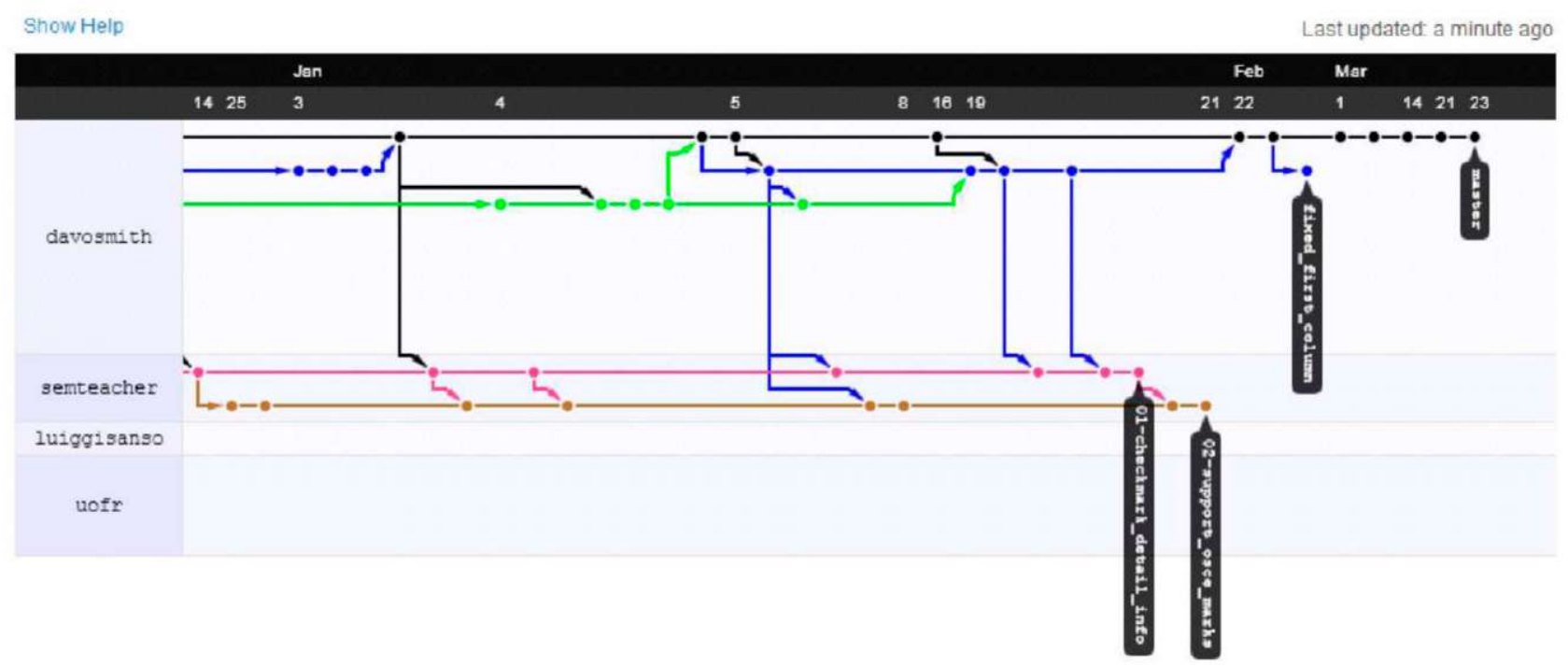

Puc. Q. Візуалізація процесу розробки - основний репозиторій модуля Checklist та гілка для ТДМУ 3 модифікаціями автора.

Нижче наведено перелік основних змін та доповнень до функціоналу модуля ведення контрольних списків, що були зроблені автором для реалізації підтримки особливостей здійснення навчального процесу в ТДМУ:

1. Реєстрація викладача, який встановив ту чи іншу відмітку, та дати і часу внесення змін. Можливість перегляду вказаної інформації студентами.

2. Функція масового встановлення відміток відразу цілій групі студентів по окремому пункту контрольного списку.
3. Формування та експорт журналу практичних навичок студентів

4. Реєстрація оцінок за іспит ОСКІ/ОСПІ, зберігання даних про викладача та дату виставлення оцінки. Можливість перегляду власних оцінок студентами.

5. Функція надсилання повідомлень електронною поштою (студенту, викладачу, або їм обом) про кожну зміну кожної відмітки матрикула чи оцінки ОСКI/ ОСПІ.

6. Здійснено локалізацію модуля українською та російською мовами. Незначні модернізації інтерфейсу. 
Також було виправлено кілька помилок головного розробника модуля, про що його було проінформовано автором. Для цього було застосовано механізм upstream pull request (запит злиття з батьківським репозиторієм) сервера GitHub. В результаті вказані виправлення було підтверджено та внесено в основний код модуля Checklist його головним розробником.
Детальніше проілюструємо окремі можливості модифікованого модуля. На рисунку 4 показано процедуру задання відміток виконання/невиконання матрикулів як відразу для всіх студентів (І на рис. 4), що їх показано на даній сторінці (для групи), так і для окремого студента (2 на рис. 4$)$.

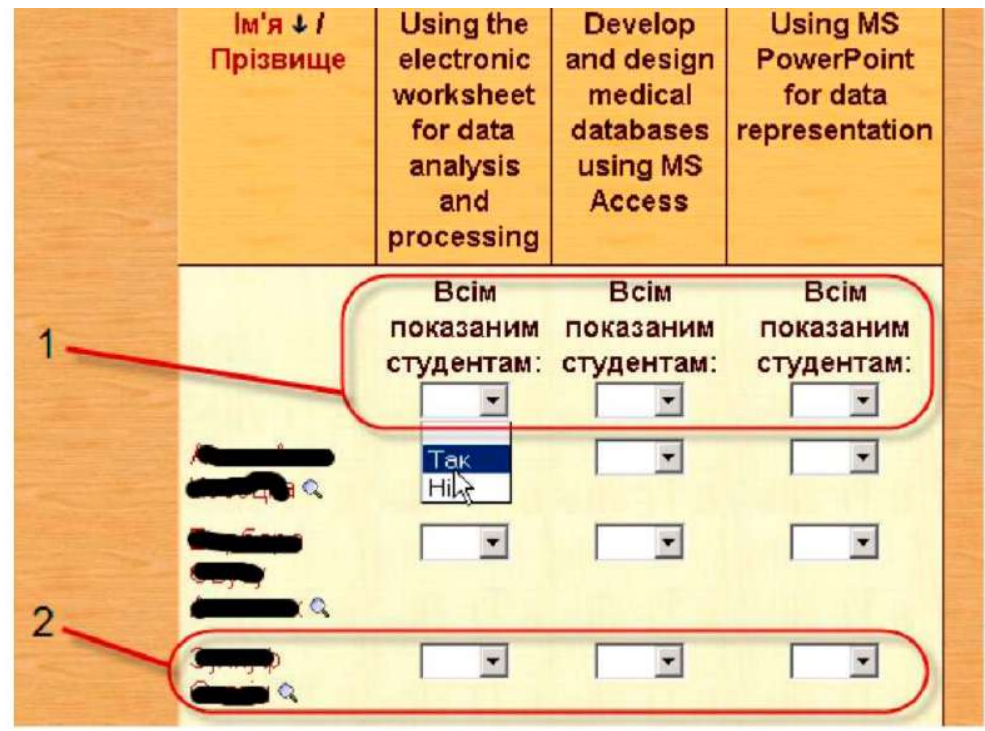

Puc. 4. Встановлення відміток виконання матрикулів для групи студентів.

Щоб отримати можливість працювати з оцінками за іспит ОСКІ/ОСПІ, викладач повинен увімкнути відповідну опцію в налаштуваннях модуля. Після цього у вікні контрольного списку з 'явиться нова закладка "Оцінки за ОСКІ" ("OSCE Marks"). Викладач має можливість виставляти як персонально (2 на рис. 5) так і відразу для цілої групи студентів (I на рис. 5) одну з визначених оцінок:
- "(пусто)" - не було спроби здавати дану практичну навичку ОСКІ/ОСПІ або така спроба була видалена;

• "1,0" - дану практичну навичку ОСКІ/ОСПІ студент виконав 3 відмінним результатом;

• "OS" - дану практичну навичку ОСКІ/ОСПІ студент виконав $з$ задовільним результатом;

- "0,0" - студент не виконав дану практичну навичку ОСКІ/ОСПІ.

\begin{tabular}{|c|c|c|c|c|c|c|}
\hline $\begin{array}{c}\text { Ім'я } \downarrow \text { | } \\
\text { Прізвище }\end{array}$ & $\begin{array}{c}\text { Зняття } \\
\text { аудіограми. }\end{array}$ & $\begin{array}{l}\text { Вимірювання } \\
\text { кров'яного } \\
\text { тиску } \\
\text { методом } \\
\text { Короткова. }\end{array}$ & $\begin{array}{c}\text { Ім'я } \downarrow \text { / } \\
\text { Прізвище }\end{array}$ & $\begin{array}{c}\text { Зняття } \\
\text { аудіограми. }\end{array}$ & $\begin{array}{c}\text { Вимірювання } \\
\text { кров'яного } \\
\text { тиску } \\
\text { методом } \\
\text { Короткова. }\end{array}$ & $\begin{array}{l}\text { Користуватися } \\
\text { апаратом для } \\
\text { гальванізації і } \\
\text { лікувального } \\
\text { електрофорезу. }\end{array}$ \\
\hline 1 & $\begin{array}{c}\text { Всім } \\
\text { показаним } \\
\text { студентам: } \\
1,0\end{array}$ & $\begin{array}{l}\text { Всім } \\
\text { показаним } \\
\text { студентам: }\end{array}$ & & $\begin{array}{c}\text { Всім } \\
\text { показаним } \\
\text { студентам: } \\
1.0=\end{array}$ & $\begin{array}{c}\text { Всім } \\
\text { показаним } \\
\text { студентам: }\end{array}$ & $\begin{array}{c}\text { Всім показаним } \\
\text { студентам: }\end{array}$ \\
\hline Áнгепіна & $1.0=$ & $\begin{array}{l}1,0 \\
0,5 h \\
0,0\end{array}$ & Ангеліна & $1,0=$ & $1,0=$ & $\begin{array}{l}1,0 \\
0,5\end{array}$ \\
\hline Андрій & $1,0=$ & $\nabla$ & Андрій & $1,0=$ & $0.5=$ & 0,0 \\
\hline
\end{tabular}




\subsection{2. Реалізація самозапису студентів на} відробки практичних занять

Наступним кроком стало запровадження восени 20I2року в ТДМУ системи самозапису студентів на відпрацювання пропущених занять. Система також реалізована автором як додатковий модуль діяльності в СДО Moodle. В її основі лежить модуль діяльності Scheduler [12], що дозволяє реалізувати діяльність з складання розкладів прийому. Даний функціональний модуль дозволяє викладачам створювати та редагувати розклади годин прийому для індивідуальних зустрічей з студентами, а також відмічати їхню присутність та виставляти оцінки. Відповідно, студенти отримують можливість реєструватися на певні години прийому та переглядати оцінки.

Аналогічно до попереднього випадку, в початковий програмний код модуля було внесено цілий ряд змін для забезпечення підтримки особливостей навчального процесу в ТДМУ, зокрема:

1. Можливість для викладача одночасно вибрати перелік $з$ кількох дат при створенні розкладу прийому відробок.

2. Можливість складання кількох розкладів (по різних навчальних дисциплінах) для одного і того самого викладача (з інтервалами часу, що перекриваються).

3. Автоматичне керування сумарною кількістю студентів, що записуються до одного і того самого викладача у інтервали прийому, які перекриваються.

4. Опціональна можливість вимагати в студента вводу даних про підстави запису на прийом (причина відпрацювання і т. п.).
5. Попередньо задані налаштування, оптимальні для використання в ТДМУ. Проведено незначну модернізацію інтерфейсу та виправлено кілька дрібних помилок.

6. Здійснено локалізацію українською та російською мовами.

Першу версію програмного коду модуля з вказаними змінами (для СДО Moodle версії 1.9) було опубліковано сервері GitHub в репозиторії автора (https://github.com/semteacher/moodletdmumod_scheduler19). Слід відмітити, що підтримка модуля діяльності Scheduler для СДО Moodle версії 1.9 на той момент вже була припинена основним його розробником. В процесі оновлення СДО Moodle до версії 2.х відповідні зміни були повторно реалізовані автором в актуальній версії модуля діяльності Scheduler. Сам модифікований модуль також опубліковано, тепер уже як відгалуження основного проекту, в репозиторії автора (https:// github.com/semteacher/moodle-mod_scheduler/) на сервері GitHub (див. рис. 6).

Детальніше проілюструємо окремі можливості модифікованого модуля. На рисунку 7 показано діалог добавлення розкладу на заданий перелік дат. В його основі лежить елемент керування "календар", який дозволяє вибрати (відмітити) довільну кількість дат. На кожну 3 цих дат буде створено інтервали прийому (відробки) у вказані години. Більшість параметрів уже мають встановлені по замовчуванню значення, що відповідають рекомендованим для використання у ТДМУ.

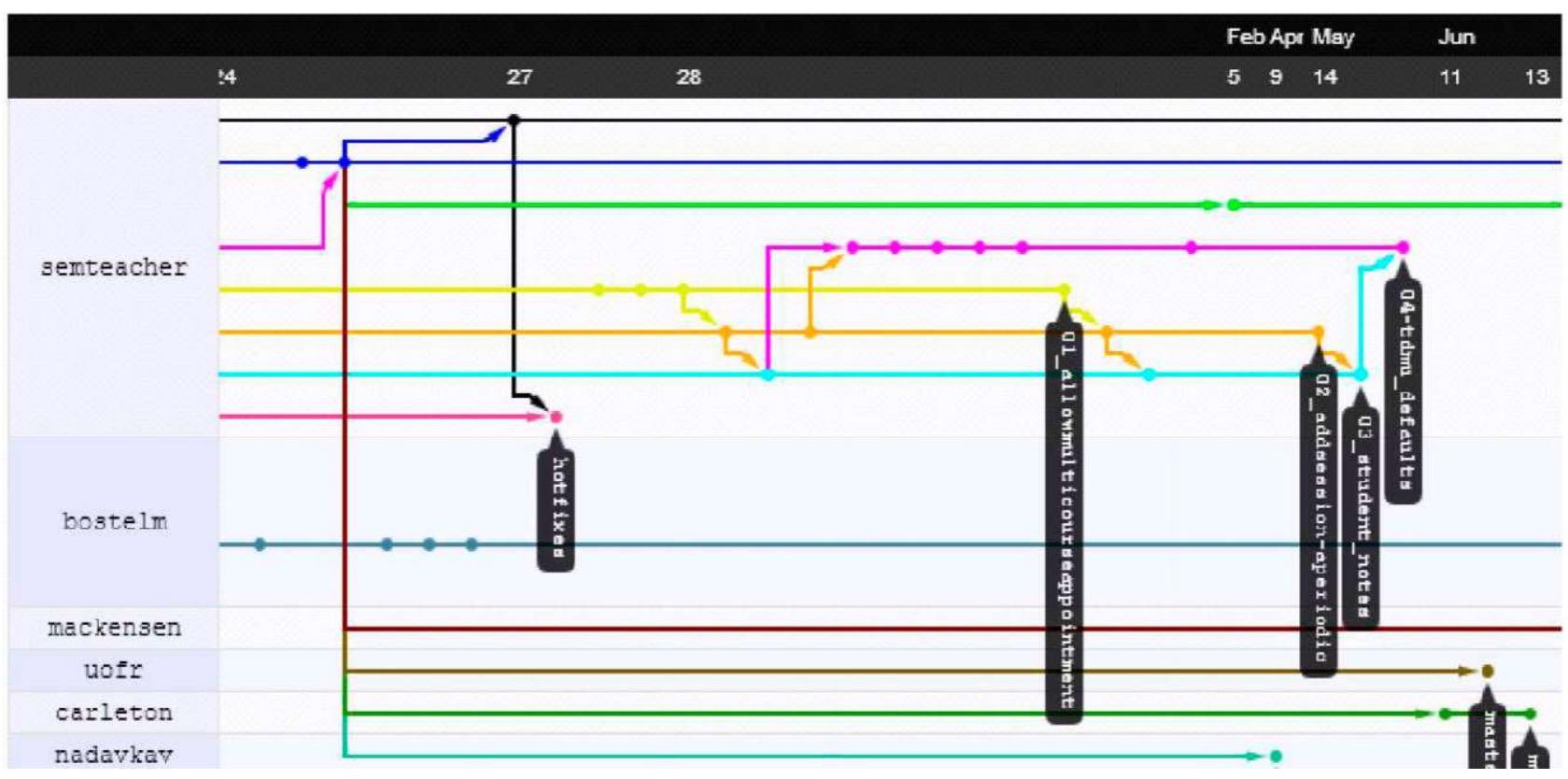

Puc. 6. Візуалізація процесу розробки модуля Schedulerr ${ }^{\pi}$ гілка для ТдМУ з модифікаціями автора. 


\section{Додати інтервали - вільно}

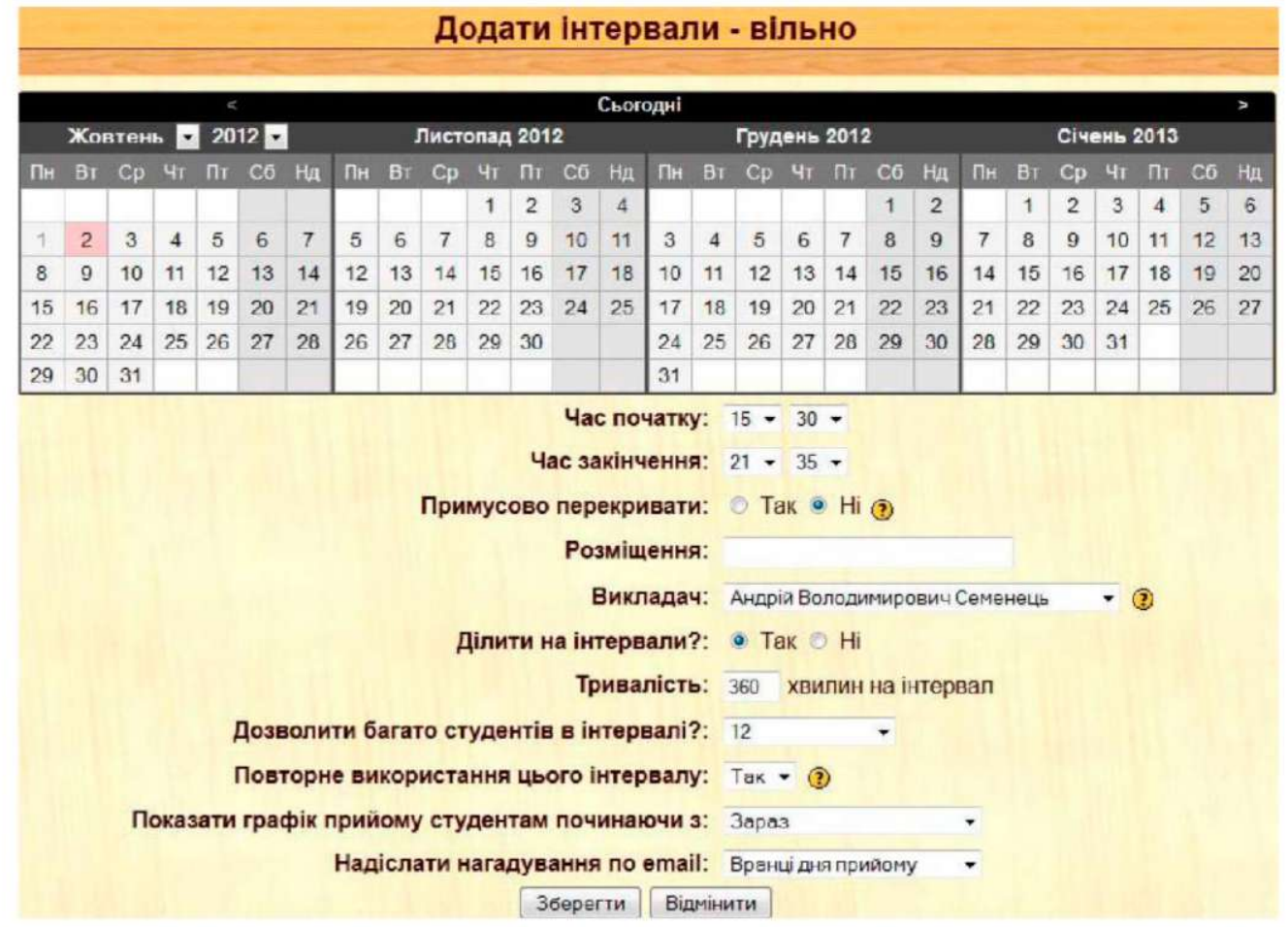

Puc. 7. Діалог додавання розкладу на заданий перелік дат.

Процес запису студента на відробку практичного заняття показано на рисунку 8. Можна побачити ви- браний інтервал прийому, вже записані інші студенти та вікно запиту підстав для відробки:

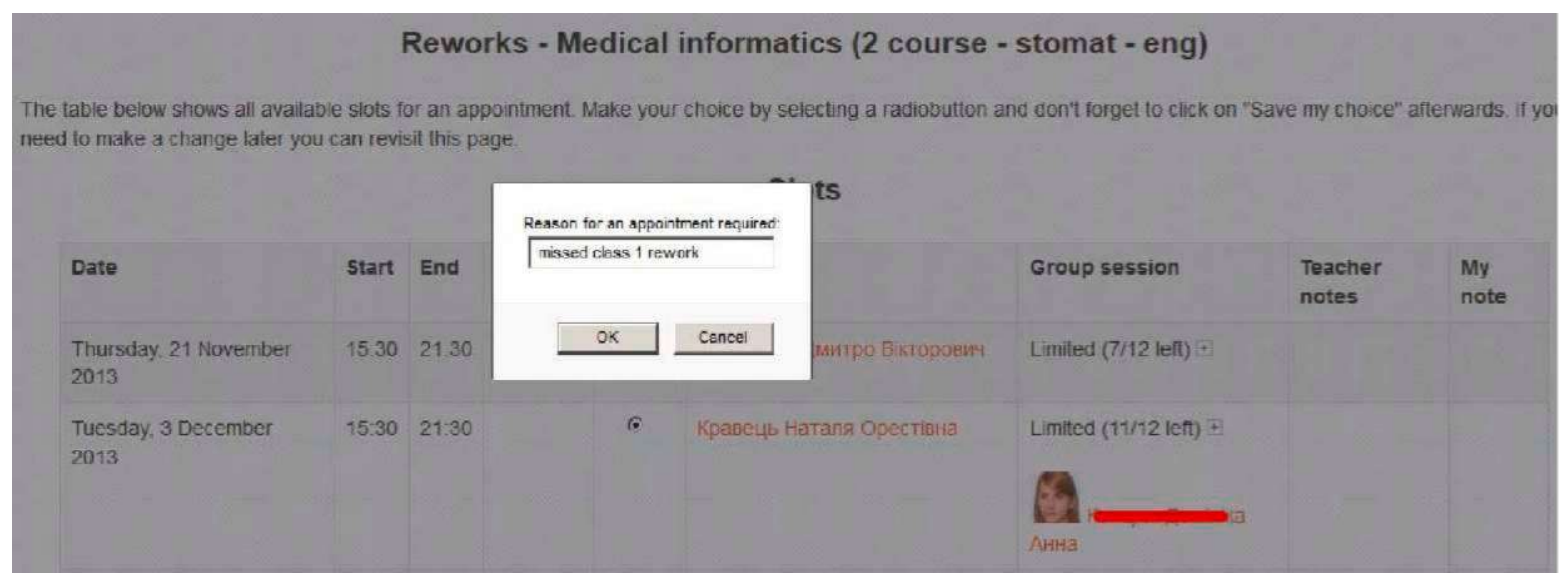

Puc. 8. Процес самозапису студена на відробку.

Вигляд панелі викладача модуля самозапису з переліком студентів, що вже записалися на відробки практичних занять, показано на рисунку 9. На даній сторінці викладачу доступні такі елементи керування розкладом прийому (відробкою):

1. Прапорці, що призначені для встановлення відмітки про те, що студент з'явився на прийом (відробку).

2. Прізвища студентів, що записалися на прийом (відробку).
3. Інформація про оцінку (якщо режим оцінювання увімкнено).

4. Кнопка, що зберігає зміни в статусі "з'явився/ не з'явився".

5. Перемикання між індивідуальним та груповим режимом прийому.

6. Анулювання всіх записів на прийом по даному часовому інтервалу. 


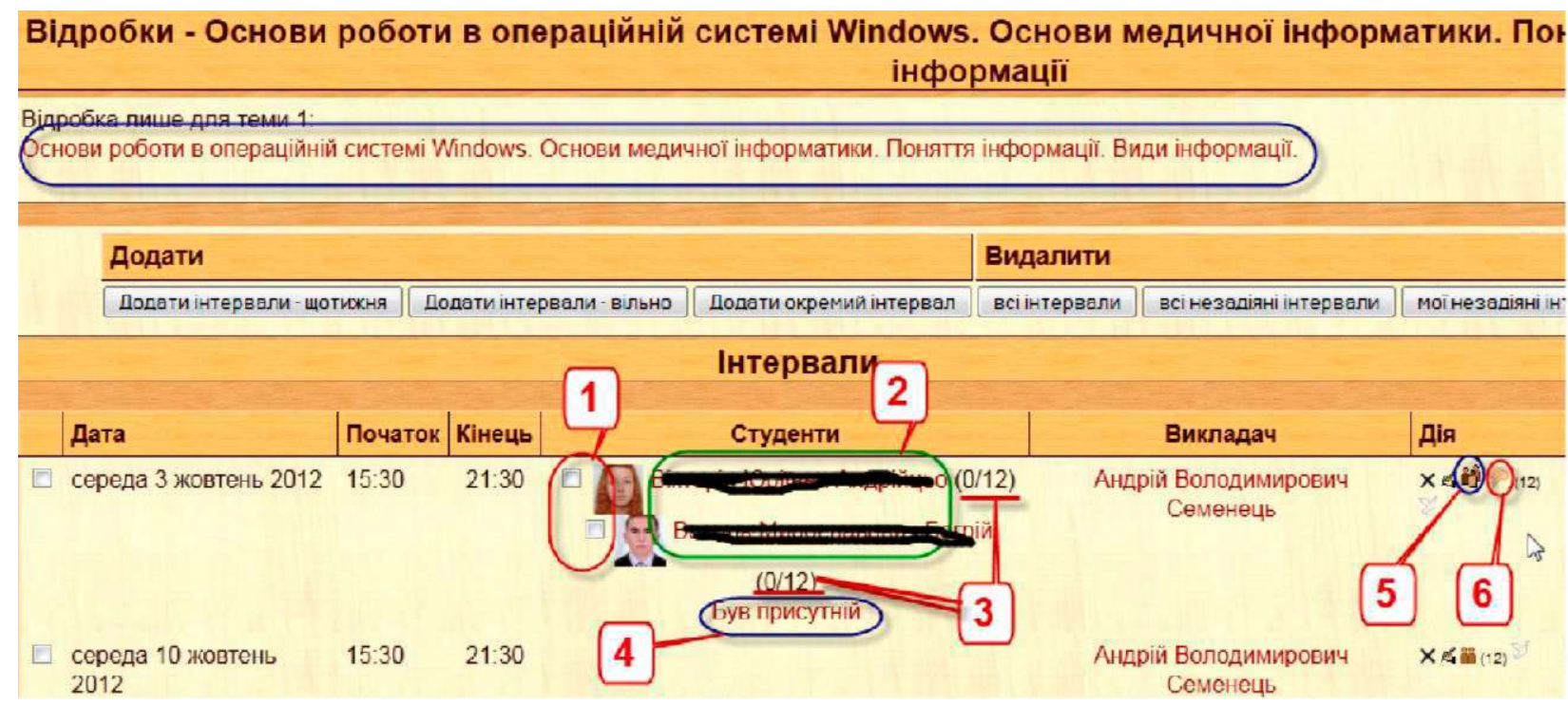

Puc. 9. Розклад відробок з записаними студентами.

\section{Висновки}

Впровадження інформаційно-комунікаційних технологій - необхідна умова підвищення якості медичної освіти. Застосування вільно розповсюджуваного ПЗ 3 відкритим кодом є складовим елементом сучасного підходу до реалізації навчального процесу в медичній освіті.

СДО Moodle - один з лідерів серед вільно розповсюджуваного ПЗ СКН/СДО/СКНМ з відкритим кодом. Широкі функціональні можливості дозволяють ефективно використовувати його в усіх галузях освіти. А доступність вихідного коду через систему контролю версій робить процес модифікації та адаптації даного ПЗ прозорим та зрозумілим.

\section{Література}

1. Авраменко В. I. Формування основних напрямків розвитку інформаційних технологій в охороні здоров'я України на основі світових тенденцій / В. І. Авраменко, В. О. Качмар // Український журнал телемедицини та медичної телематики. - 2011. - Т. 9, №2 - С. 5-15.

2. Фетісов В. С. Комп'ютерні технології в тестуванні. / В. С. Фетісов [Електронний ресурс] / 2011. - Режим доступу до документу : http://moodle.ndu.edu.Ua/file.php/1/ Petisov_komp_tehnol_v-testuvanni.pdf

3. Центри ДО в Україні // Освітній портал/ [Електронний pecypc] - Режим доступу до документу : http:// www.osvita.org.ua/distance/ukraine/centers/

4. Дистанційна Освіта в Україні / [Електронний ресурс] Режим доступу до документу : http://ib.if.ua/publish2008/ 1217424966.html
Завдяки великій спільноті розробників для СДО Moodle $\epsilon$ в наявності широкий вибір різноманітних модулів та додатків, що значно розширюють та доповнюють функціональність основного програмного пакету. Слід додати, що програмний код фактично всіх цих додаткових модулів також доступний через систему контролю версій, a, отже, також може бути адаптований до вимог конкретної галузі освіти чи навчального закладу.

Вказані можливості застосування та адаптації СДО Moodle та його додаткових модулів і були продемонстровані в роботі на прикладі досвіду використання вказаного СДО в Тернопільському державному медичному університеті ім. І. Я. Горбачевського.

5. Moodle.org: Registered sites / [Електронний pecypc] Режим доступу до документу : https://moodle.org/sites/ index.php? country $=\mathrm{UA}$

6. List of learning management systems - Wikipedia, the free encyclopedia/ [Електронний pecypc] Режим доступу до документу : http://en.wikipedia.org/ wiki/Listoflearningmanagementsystems

7. Search Results for "lms": SourcePorge/ [Електронний pecypc] - Режим доступу до документу : http:// sourceforge.net/directory/developmentstatus:production/?q=1ms

8. UpgradingtoMoodle $2.0 /$ [Електронний ресурс] Режим доступу до документу : http://docs.moodle.org/20/ en/Upgrading_to_Moodle_2.0

9. Ковальчук Л. Я. Впровадження нової методики навчального процесу в Тернопільському державному медично- 


\section{МЕДИЧНА ІНФОРМАТИКА}

\section{TA ІНЖЕНЕРІЯ}

му університеті імені І. Я. Горбачевского // Медична освіта. - 2007. - № 2. - С. 16-20.

10. Checklist - Checklist activity module, block and grade export plugins [Електронний ресурс] / Режим доступу до сайту : http://moodle.org/plugins/browse.php?list=set\&id=7

11. Марценюк В. П. Модуль реєстрації виконання студентами матрикулів практичних навичок та оцінок за ОСКІ в системі електронного контролю знань на базі СДО Moodle. / В.П. Марценюк, А. В. Семенець // Запорожский медицинский журнал. - 2013. - № 1. - С. 26-27.

12. Moodle Plugins Directory: Scheduler/ [Електронний peсурс] - Режим доступу до документу : https://moodle.org/plugins/view.phpCpluginamodscheduler 